\title{
Naphthyl-fused phosphepines: Luminescent contorted polycyclic P-heterocycles
}

\author{
Thomas Delouche, ${ }^{[a]}$ Réka Mokrai, ${ }^{[a, b]}$ Thierry Roisnel, ${ }^{[a]}$ Denis Tondelier, ${ }^{[c]}$ Bernard Geffroy, ${ }^{[d]}$ László \\ Nyulászi, ${ }^{[b, e]}$ Zoltán Benkő, ${ }^{*[b]}$ Muriel Hissler ${ }^{*[a]}$ and Pierre-Antoine Bouit*[a]
}

\begin{abstract}
: the article presents the synthesis of a new family of naphthyl-fused phosphepines through $\mathrm{Ni}$-mediated $\mathrm{C}-\mathrm{C}$ coupling. Interestingly, the chloro-phosphine-oxide intermediate shows strong resistance toward oxidation/hydrolysis due to a combination of steric hindrance and pnictogen interactions. However it can undergo substitution reactions under specific conditions. The optical / redox properties and the electronic structure of these new $\pi$-systems were studied experimentally (UV-vis absorption, emission, cyclic voltammetry) and computationally (TD-DFT calculations, NICS investigation). Taking advantage of the luminescence of these derivatives, a blue emitting OLED has been prepared highlighting that these novel $\pi$ conjugated P-heterocycles appear as promising building blocks for solid-state lightning applications.
\end{abstract}

\section{Introduction}

During the last two decades, the research on phosphoruscontaining $\pi$-conjugated systems based on small molecules, oligomers and polymers has increased substantially thanks to the development of "plastic electronic" devices. ${ }^{[1]}$ Compared to purely organic $\pi$-systems, the presence of a heteroatom such as phosphorus affords multiple molecular engineering strategies in order to tune the chemical structure and the physico-chemical properties. Indeed, the $\mathrm{P}$-atom can be involved in various bonding situations $\quad\left(\sigma^{3}, \lambda^{3}\right.$-phosphane, $\sigma^{2}, \lambda^{3}$-phosphaalkene, $\sigma^{1}, \lambda^{3}$ phosphaalkyne etc), which strongly impacts the nature of the delocalization in the corresponding $\pi$-system..$^{[2]}$ Furthermore, the specific reactivity of the $\sigma^{3}, \lambda^{3}-\mathrm{P}$-atom affords an almost unlimited way of tuning its properties. [3] Among these strategies, introducing the P-center into an unsaturated ring is also an excellent way to modify the properties of the corresponding $\pi$ system. Phosphole, the P-analogue of thiophene, is by far the most studied P-heterocycle based $\pi$-system from the point of view

[a] T. Delouche, R. Mokrai, T. Roisnel, Prof. M. Hissler, Dr P.-A. Bouit Univ Rennes, CNRS, ISCR - UMR 6226, F-35000 Rennes.

E-mail: muriel.hissler@univ-rennes1.fr, pierre-antoine.bouit@univrennes1.fr

[b] Department of Inorganic and Analytical Chemistry, Budapest University of Technology and Economics Szt. Gellert ter $4 \mathrm{H}-1111$ Budapest, Hungary

E-mail: zbenko@mail.bme.hu

[c] LPICM, CNRS, Ecole Polytechnique, IPParis, 91128 Palaiseau, France

[d] LICSEN, NIMBE, CEA, CNRS, Université Paris-Saclay, CEA Saclay, 91191 Gif-sur- Yvette Cedex, France

[e] MTA-BME Computation Driven Chemistry Research Group. Szt. Gellert ter $4 \mathrm{H}-1111$ Budapest, Hungary

E-mail: nyulaszi@mail.bme.hu of its reactivity as well as for its introduction into devices (lightemitting diodes, solar cells, batteries...).[ $\left.{ }^{4}\right]$ However, P. heterocycles are not limited to the phosphole family and during the last few years, other $\pi$-systems based on phosphetenes (4membered unsaturated P-ring), [ 5 ] phosphaphenalenes / phosphinines (6-membered P-ring $)^{[6]}$ or phosphepines (7 membered P-rings) ${ }^{[7]}$ have started to be studied in the context of molecular materials. The phosphepine ring caught our attention as it displays the most distorted framework among these conjugated heterocycles, which may strongly impact the physicochemical properties. In particular, we and others studied nonplanar diarylophosphepines (B, Scheme 1) showing tunable optical/redox properties and promising activity in field-effect transistors. ${ }^{[8]}$ Those diarylophosphepines are usually synthesized according to a classical sequence of dilithiation of a dibromoaryl then reaction with a dichlorophosphine (Scheme 1). In order to develop a new family of $\pi$-extended-phosphepine, we decided to adapt the Ni-mediated coupling strategy that allowed M. Wagner et al to prepare distorted borepins and thus investigate the effect of the insertion of a P-atom into such quadruply-fused phosphepine D (Scheme 1). ${ }^{[9]}$ In this article, we present the synthesis of a new family of naphthyl-fused phosphepines. The optical and redox properties and the electronic structure of these new $\pi$-systems have been studied experimentally and computationally. Incorporation of one of these molecules into an OLED device has also been performed.

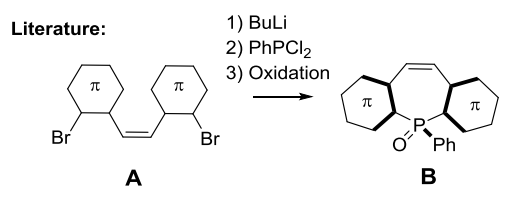

This article:

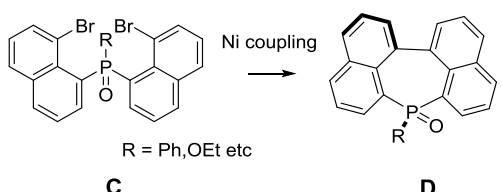

Scheme 1. Reported access to $\pi$-extended phosphepine (B) and synthetic strategy employed in this article. 


\section{Results and Discussion}

Synthesis and structural study of precursors

Based on our synthetic strategy toward D (Scheme 1), the first step of our approach was the preparation of the bromonaphthylphosphines $\mathbf{C}$. The reaction between 1,8-dibromonaphthalene 1 and BuLi followed by in situ addition of dichlorophenylphosphine and subsequent oxidation afforded quantitatively a product characterized by a single peak in the ${ }^{31} \mathrm{P}$ NMR spectrum $(\delta=$ $+42.9 \mathrm{ppm}$ ) and broad multiplets in the ${ }^{1} \mathrm{H}$ NMR (Fig. S8). This phenomenon is due to the presence of interconverting rotamers at room temperature (rt). Indeed, the signals in the ${ }^{1} \mathrm{H} N M R$ sharpened upon cooling the temperature to $243 \mathrm{~K}$ (Fig. S8). ${ }^{\mathrm{g}} \mathrm{l}$ The product was unambiguously characterized as 2 by its crystallographic structure (Scheme 2 and Fig. 1). The molecular structure of 2 displays high steric hindrance with torsion of the naphthyl ring as well as presence of intramolecular contacts shorter than the sum of van der Waals radii $\left(\mathrm{d}_{\mathrm{vdW}}\right)$ between $\mathrm{O}$ and $\operatorname{Br}\left(3.122 \AA<\mathrm{d}_{\mathrm{OBr}}<3.144 \AA\right.$, see Fig $\left.1, \mathrm{~d}_{\mathrm{vdw}}(\mathrm{O}-\mathrm{Br})=3.37 \AA\right)$ and especially between $\mathrm{P}$ and $\mathrm{Br}$ centers $\mathrm{Br}\left(3.246 \AA<\mathrm{d}_{\mathrm{PBr}}<3.399 \AA\right.$, see Fig $\left.1, d_{v d w}(P-B r)=3.65 \AA\right)$. This sterically crowded structure with intramolecular interactions can explain the presence of interconverting rotamers at rt.

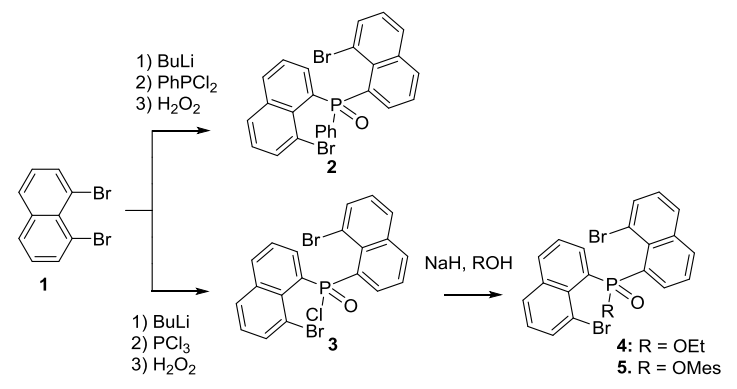

Scheme 2. Syntesis of bromonaphthyl substituted phosphine oxide 2-4.

The same sequence was then performed using $\mathrm{PCl}_{3}$ as starting phosphine and the product identified after oxidation was the chlorophosphine oxide 3 (Scheme 2). This compound displays similar NMR behaviour as 2 with broad ${ }^{1} \mathrm{H}$ signals that resolved upon cooling to temperature (Fig. S9). Furthermore, X-ray diffraction allowed the unambiguous characterization of 3 (Fig. 1). The high steric hindrance around the $\mathrm{P}$-atom combined with the presence of intramolecular short contacts $\left(3.204 \AA<\mathrm{d}_{\mathrm{OB}}<3.300 \AA\right.$, $3.246 \AA<\mathrm{d}_{\mathrm{PBr}}<3.399 \AA$, Fig 1) probably allows sterically protecting the $\mathrm{P}-\mathrm{Cl}$ bond making 3 fully air and moisture stable. This is surprising because chlorophosphine-oxides are usually sensitive to hydrolysis. Nevertheless, the $\mathrm{Cl}$ atom of $\mathbf{3}$ could be substituted by alkoxides/aryloxides to afford 4 and 5 (Scheme 2). Their structures could be confirmed by X-ray diffraction (Fig S13-14).

In order to gain more insight into the nature of the weak interactions we have performed DFT calculations at different levels, here only the results obtained at the B3LYPD3/6-31+G* level are discussed. To estimate the energetic stabilization caused by these interactions, the corresponding isodesmic reaction depicted in Scheme $\mathrm{S} 1$ has been calculated for compounds 2 and $\mathbf{3}$. Remarkable stabilization reaching 18.5 $\mathrm{kcal} / \mathrm{mol}$ is found in $\mathbf{3}$, while somewhat smaller but still significant value of $14.8 \mathrm{kcal} / \mathrm{mol}$ is obtained for 2 . The covalent character of possible $\mathrm{P} \cdots \mathrm{Br}$ and $\mathrm{O} \cdots \mathrm{Br}$ interactions has been assessed employing Wiberg Bond Indices (WBI). This shows practically no interaction between the $\mathrm{O}$ and $\mathrm{Br}$ centers (WBI: 0.007), whereas the $\mathrm{WBI}$ value for both $\mathrm{P}-\mathrm{Br}$ pairs in the range of $\sim 0.02$ may indicate pnictogen interaction between $\mathrm{P}$ and $\mathrm{Br} \cdot{ }^{[10-11]}$ The presence of weak interactions between the $\mathrm{P}$ and $\mathrm{Br}$ atoms is further corroborated by an atoms in molecules (AIM) analysis of the electron density (see ESI, Fig S25). In conclusion, a weak pnictogen interaction between $\mathrm{P}$ and $\mathrm{Br}$ may contribute to the particular stability of $\mathbf{3}$, that can be easily handled in air and purify with classical chromatography techniques.
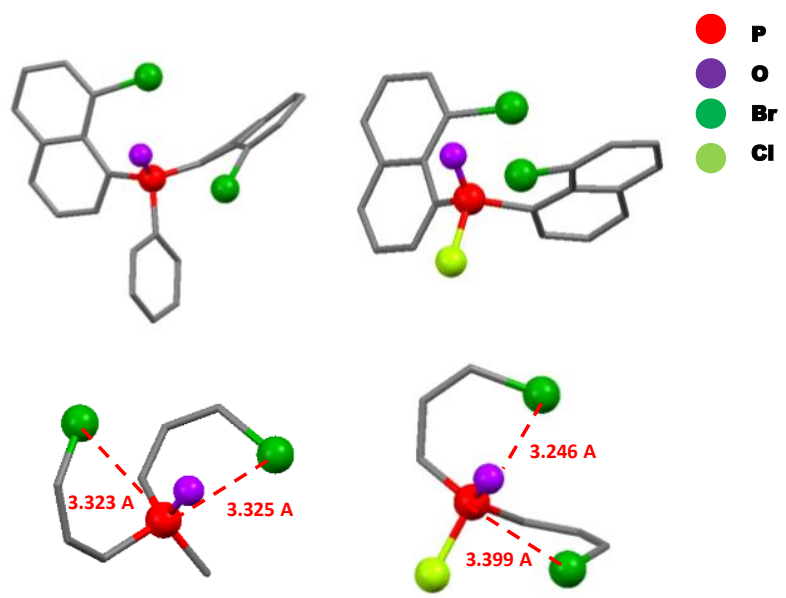

Figure 1: Crystallographic structures of 2 (left) and $\mathbf{3}$ (right) (top) with zooms on the $\mathrm{P}$ environment with measured $\mathrm{P}-\mathrm{Br}$ distances (red dotted line) (down). Hydrogen atoms were omitted for clarity.

Synthesis and structural study of naphthyl-fused phosphepines

The fusing step toward $\mathbf{D}$ (Scheme 1) was then tested employing the Yamamoto-type conditions optimized by Wagner et al. [g] using 2 equiv. of $\mathrm{Ni}(\mathrm{COD})_{2}, \mathrm{COD}$ (2 equiv.) and bpy in THF allowed us to convert 2 into 6 ( ${ }^{31} \mathrm{P}$ NMR: $\delta=+22.7 \mathrm{ppm}$ ) in good yields (75\%) (Scheme 4). 5 was characterized by multinuclear NMR, HRMS and X-ray diffraction (Fig. 2). Based on these results, the $\mathrm{Ni}$-mediated coupling was used to prepare 7-8 in good yields (75\% and $47 \%$, respectively). These examples show that the Yamamoto-type reaction is an efficient way to prepare unprecedented naphtyl-fused phosphepines from the corresponding bromo-naphthylphosphines. As expected for contorted polycyclic aromatic systems, the solubility of these 
compounds in most organic solvents (DCM, AcOEt, THF...) is rather good.

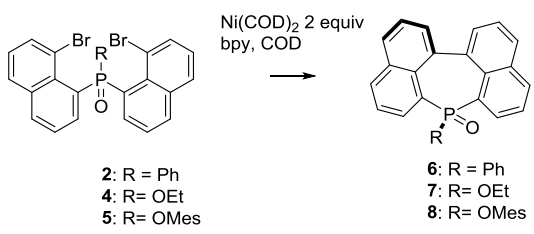

Scheme 4. Synthesis of naphthyl-fused phosphepines 6-8

Additionally, $\mathbf{6}$ and $\mathbf{8}$ were also characterized by X-ray diffraction. They both show similar structural features (Table 1) so the following paragraph will only detail 6 . The P-C bonds lengths are classical for phosphine-like structures ( $\mathrm{d}_{\mathrm{P}-\mathrm{C}}=1.79-1.81 \AA$ ). In the 7-membered P-ring, all $\mathrm{C}-\mathrm{C}$ bonds belonging to the naphthalene moiety are within the aromatic C-C distances $(1.42 \AA<d<1.44 \AA)$ while C3-C4 has clearly a single bond character $(\mathrm{d}=1.513 \AA$ ) .6 displays a highly distorted $\mathrm{C}$-backbone as illustrated by the $\mathrm{C}_{13} \mathrm{C}_{3} \mathrm{C}_{4} \mathrm{C}_{20}$ torsion angle of $38.9^{\circ}$. The distorted nature of the polycyclic framework in 6-8 is also verified by DFT calculations in the gas phase and the calculated characteristic distances and angles clearly match the experimental data obtained from X-ray diffraction (for details see ESI). Despite the distortion of the backbone, $\pi$-dimers $(d=3.567 \AA$ ) are observed along the $b$ axis in the packing. These dimers are also engaged in $\pi$-stacking interactions $(d=3.735 \AA$ ) to form infinite $\pi$-columns. a)

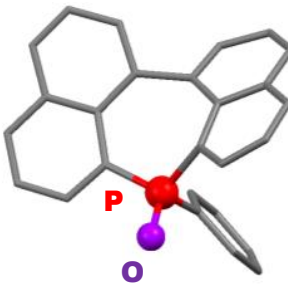

b)

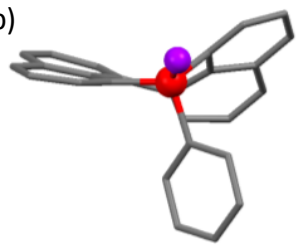

c)

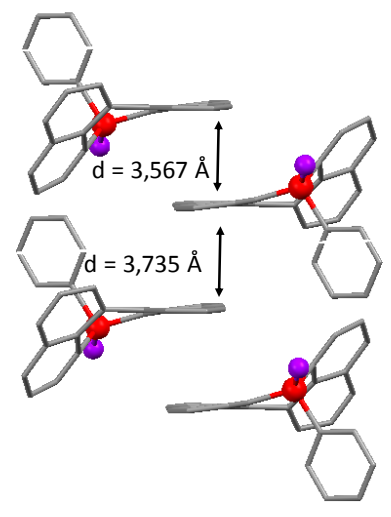

Figure 2: Top (a) and lateral (b) crystallographic views of 6 . Columns observed in the packing (c). Hydrogen atoms were omitted for clarity.
Table 1. Characteristic distances and angles taken from X-ray diffraction.

\begin{tabular}{|c|c|c|}
\hline & 6 & 8 \\
\hline $\mathrm{P}-\mathrm{C}_{1}(\AA)$ & 1.787 & 1.782 \\
\hline $\mathrm{P}-\mathrm{C}_{6}(\AA)$ & 1.801 & 1.777 \\
\hline $\mathrm{C}_{1}-\mathrm{C}_{2}(\AA)$ & 1.442 & 1.426 \\
\hline $\mathrm{C}_{2}-\mathrm{C}_{3}(\mathrm{~A})$ & 1.426 & 1.441 \\
\hline $\mathrm{C}_{3}-\mathrm{C}_{4}(\mathrm{~A})$ & 1.513 & 1.514 \\
\hline $\mathrm{C}_{4}-\mathrm{C}_{5}(\AA)$ & 1.422 & 1.445 \\
\hline $\mathrm{C}_{5}-\mathrm{C}_{6}(\mathrm{~A})$ & 1.426 & 1.435 \\
\hline $\mathrm{C}_{1}-\mathrm{P}-\mathrm{C}_{2}\left({ }^{\circ}\right)$ & 110.98 & 107.54 \\
\hline $\mathrm{C}_{13}-\mathrm{C}_{3}-\mathrm{C}_{4}-\mathrm{C}_{20}$ & 38.88 & 30.40 \\
\hline
\end{tabular}

Optical and redox properties

In order to further establish structure-property relationships in this novel family of $\pi$-conjugated $\mathrm{P}$-heterocycles 6-8, their UV-Vis absorption spectra were measured in $\mathrm{CH}_{2} \mathrm{Cl}_{2}$ (Fig. 3 and Fig. $\mathrm{S} 17$ ), as well as their fluorescence spectra were obtained both in solution and in solid-state and their cyclic voltammetry was measured in DMF with $\mathrm{Bu}_{4} \mathrm{NPF}_{6}$ as electrolyte (Table 1).

The UV-Vis absorption spectrum of the naphthyl-fused phosphepine 6 consists of a band with an absorption maximum centered at $\lambda_{\mathrm{abs}}=346 \mathrm{~nm}$ (Fig. 3 and Table 1). This absorption is only weakly modified upon modification of the exocyclic $\mathrm{P}-\mathrm{R}$ bond (for example, $\Delta \lambda(6-8)=5 \mathrm{~nm}$, see Fig. S17 and Table 1). To get more insights into the optical properties of 6-9 TD-DFT calculations have been carried out at the B3LYP/6$31 G^{*} / / B 3 L Y P / 6-31+G^{*}$ level to obtain vertical excitation energies (see Table 2 for wavelengths and Table S9 for details). ${ }^{8 b}$ These calculations confirmed that the main transition observed in UV-vis absorption is between the HOMO and LUMO orbitals (Table S9). In compounds 6-8 the HOMO and LUMO orbitals are of $\pi$ and $\pi^{*}$ type, respectively (Fig. 3 and Fig S22-23). In these orbitals the electron density is spread over the whole C-backbone, with no contribution of the P-atom in either the HOMO or the LUMO for all the computed structures (Fig. 3 and Fig. S22-23). Furthermore, the energy of these orbitals shows only a minor change upon substitution (Table 2 ), clearly explaining why the modification of the P-R bond only weakly affects the UV-vis absorption.

All phosphepines are good fluorophores with strong emission in the visible region in diluted solution. For example 6 displays a strong and unstructured emission in the visible region $\left(\lambda_{\mathrm{em}}(\mathbf{6})=\right.$ $446 \mathrm{~nm}, \phi=46 \%$, Fig 3). The remarkable Stoke shift of 6 is nicely reproduced by the TD-DFT calculations $\left(6460 \mathrm{~cm}^{-1}\right)$ and the optimized geometry of the first excited state $\left(S_{1}\right)$ indeed shows a significant distortion compared to that of that of the ground state (Fig. S24). In addition, naphthyl-fused phosphepines also display 
luminescence in powder (Fig. 3 and Table 1) as illustrated for 6 that displays emission slightly blue-shifted compared to its emission in diluted solution $\left(\lambda_{\text {em }}(6)=424 \mathrm{~nm}\right.$ with $\phi=26 \%$ Fig. $4)$. This strong solid-state luminescence is a consequence of the distorted nature of the $\pi$-framework together with the presence of the tetrahedral $\mathrm{P}$-atom which prevents efficient $\pi$-stacking and thus promote solid-state luminescence. ${ }^{[12]}$
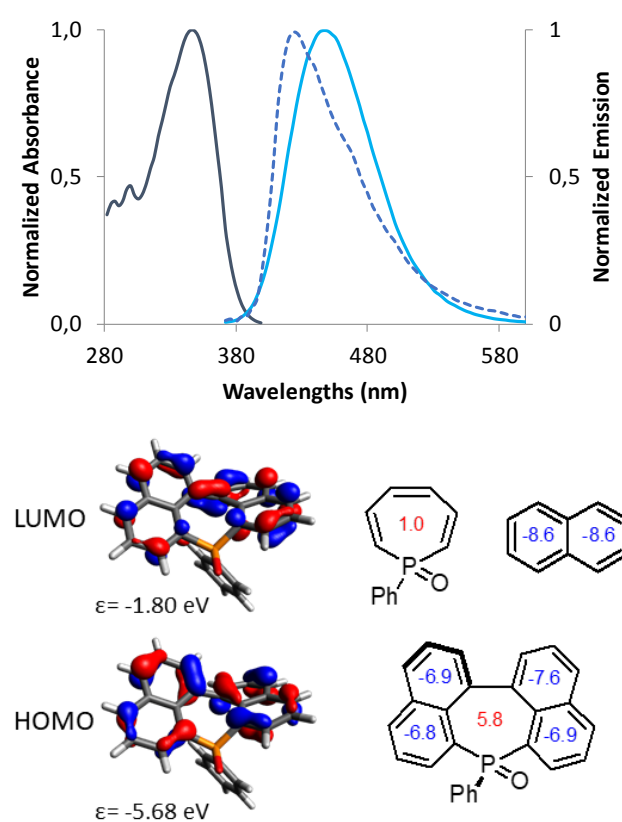

Figure 3: UV-vis absorption (dark blue) and emission (sky blue) in solution and powder (dotted line) of 6 in DCM (up); HOMO and LUMO of 6 calculated at the B3LYP/6-31G*//B3LYP/6-31+G* level (bottom, left); NICS(0) aromaticity patterns of oxa-phosphepine, naphthalene and 6 at the B3LYP/6$311+G^{\star *} / / B 3 L Y P / 6-31+G^{*}$ level (bottom, right).
Regarding the redox properties, 6-8 displays no oxidation processes either in DCM or in DMF. However, a quasi-reversible reduction process is observed at $-2.19 \mathrm{~V}$ vs $\mathrm{Fc}$ in DMF in the case of 6 . As expected, the reduction is not affected when the exocyclic $\mathrm{P}-\mathrm{R}$ bond is modified (7-8, Table 1), in line with the similar LUMO energies of these compounds (see Table 2).

The aromatic character of the rings in the fused systems 6-8 has been investigated employing Nuclear Independent Chemical Shift (NICS) calculations at the B3LYP/6-311+G**//B3LYP6-31+G* level (Fig. 3). As an example, for 6 the seven-membered ring is anti-aromatic, while the naphthalene moieties of $\mathbf{6}$ globally retain their characteristic aromatic character.

\section{OLEDs devices}

Taking in account its thermal stability $\left(\operatorname{td}_{10}=338^{\circ} \mathrm{C}\right)$ and its favorable electronic properties (vide supra), compound 6 was used as emitting material (EM) doped in 1,3-bis $(\mathrm{N}$ carbazolyl)benzene (mCP) host in a multilayer OLED device (see exp. section). The performances of the OLED devices are reported in Table 3 and Fig. 4 for different concentrations of 6 in the $\mathrm{mCP}$ host. When the $\mathrm{mCP}$ matrix is doped with $\mathbf{6}$, the emission spectra are changed from emission of $\mathrm{mCP}$ (main peak at $404 \mathrm{~nm})$ to the emission of $6\left(\lambda_{\mathrm{em}}=436 \mathrm{~nm}\right)$. From a doping rate of $1.5 \%$, we can note that the energy transfer from the host to the guest is complete. The devices emit a deep blue color with low CIE (Commission internationale de l'éclairage) color coordinates. Interestingly, the efficiency of the devices is almost independent of the doping rate in the range 1.5 to $3.7 \%$ with external quantum efficiency (EQE) of $1.6 \%$. For doping rate as high as $70 \%$, the EQE drops to $0.7 \%$ with no significant change of the emission spectrum. This can be explained by the low charge transport of 6 which is detrimental to the efficiency of the device.

Table 2. Photophysical and redox data.

\begin{tabular}{|c|c|c|c|c|c|c|c|c|c|}
\hline & $\begin{array}{c}\lambda_{\text {abs }}^{[\mathrm{a}]}\left(\lambda_{\mathrm{abs}}^{\mathrm{DFT}}\right)^{[\mathrm{b}]} \\
{[\mathrm{nm}]}\end{array}$ & $\begin{array}{c}\varepsilon^{[\mathrm{a}]} \\
{\left[\mathrm{L} . \mathrm{mol}^{-1} \cdot \mathrm{cm}^{-1]}\right.}\end{array}$ & $\begin{array}{c}\lambda_{\mathrm{em}}{ }^{[\mathrm{a}]}\left(\lambda_{\mathrm{em}}^{\mathrm{DFT}}\right)^{[\mathrm{b}]} \\
{[\mathrm{nm}]}\end{array}$ & $\Phi_{\mathrm{F}}^{[\mathrm{c}]}$ & $\begin{array}{c}\lambda_{\mathrm{em}}{ }^{[\mathrm{c}]} \\
{[\mathrm{nm}]}\end{array}$ & $\Phi_{\mathrm{F}}^{[\mathrm{d}]}$ & $\begin{array}{c}\mathrm{E}^{\mathrm{red}[\mathrm{e}]} \\
{[\mathrm{V}]}\end{array}$ & $\begin{array}{c}\varepsilon^{\mathrm{HOMO}[\mathrm{b}]} \\
{[\mathrm{eV}]}\end{array}$ & $\begin{array}{c}\varepsilon^{\text {LUMO [b1 }} \\
{[\mathrm{eV}]}\end{array}$ \\
\hline 6 & 346 (357) & 14000 & $446(464)$ & 0.46 & 424 & 0.26 & $-2.19^{[f]}$ & -5.68 & -1.80 \\
\hline 7 & $346(361)$ & 10500 & $442(453)$ & 0.46 & 432 & 0.27 & $-2.20^{[f]}$ & -5.64 & -1.82 \\
\hline 8 & $351(370)$ & 14000 & $442(458)$ & 0.46 & 513 & 0.09 & $-2.18^{[f]}$ & -5.65 & -1.91 \\
\hline
\end{tabular}

[a] In $\mathrm{CH}_{2} \mathrm{Cl}_{2}\left(10^{-5} \mathrm{M}\right)$. [b] Calculated at the B3LYP/6-31G*//B3LYP/6-31+G* level [c] Measured relative to quinine sulfate $\left(\mathrm{H}_{2} \mathrm{SO}_{4}, 1 \mathrm{~N}\right)$, $\phi$ ref $=0.546$. [d] Measured in calibrated integrated sphere. [e] In DMF with $\mathrm{Bu}_{4} \mathrm{~N}^{+} \mathrm{PF}_{6}{ }^{-}(0.2 \mathrm{M})$ at a scan rate of $100 \mathrm{mV} . \mathrm{s}^{-1}$. Potentials vs $\mathrm{Fc}^{+} / \mathrm{Fc}$. [f] quasi-reversible process. 
Table 3. OLEDs devices performances

\begin{tabular}{cccccc}
$\begin{array}{c}\text { Doping } \\
\text { ratio [\%] }\end{array}$ & $\begin{array}{c}\mathrm{Von}^{[\mathrm{a}]} \\
{[\mathrm{V}]}\end{array}$ & $\begin{array}{c}\mathrm{EQE}^{[\mathrm{b}]} \\
{[\%]}\end{array}$ & $\mathrm{cd} / \mathrm{A}^{[\mathrm{b}]}$ & $\begin{array}{c}\mathrm{Peak}^{[\mathrm{c}]} \\
{[\mathrm{nm}]}\end{array}$ & $\mathrm{CIE}(\mathrm{x} ; \mathrm{y})^{[\mathrm{b}]}$ \\
0 & 4.6 & 0.7 & 0.4 & 404 & $0.167 ; 0.110$ \\
1.5 & 4.1 & 1.6 & 0.9 & 436 & $0.151 ; 0.075$ \\
2.6 & 4.1 & 1.6 & 1.0 & 436 & $0.151 ; 0.077$ \\
3.1 & 4.3 & 1.5 & 0.9 & 436 & $0.150 ; 0.083$ \\
3.7 & 4.2 & 1.6 & 1.1 & 436 & $0.150 ; 0.086$ \\
70 & 3.7 & 0.7 & 0.5 & 436 & $0.161 ; 0.092$ \\
\hline
\end{tabular}

[a] recorded at luminance of $0.1 \mathrm{~cd} / \mathrm{m}^{2}$, ${ }^{[b]}$ recorded at $30 \mathrm{~mA} / \mathrm{cm}^{2},{ }^{[c]}$ main peak.

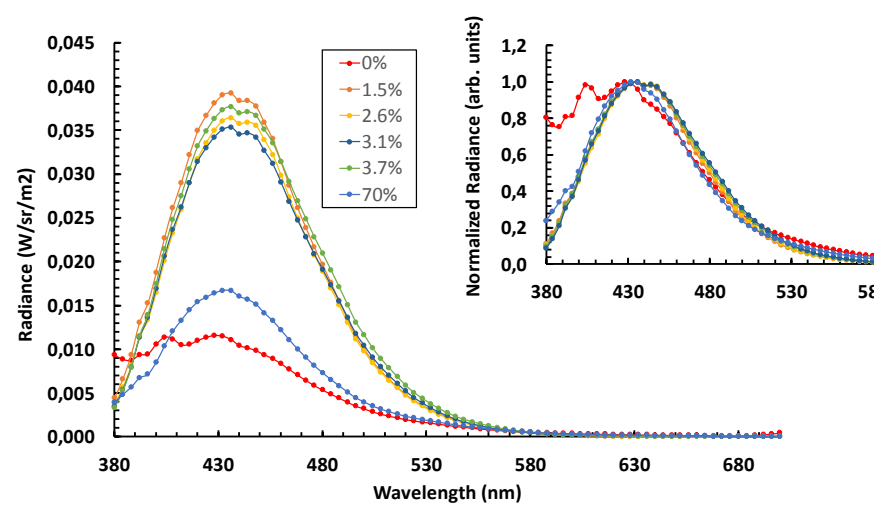

Figure 4: OLEDs spectra recorded at $30 \mathrm{~mA} / \mathrm{cm}^{2}$ for different doping rates. Insert shows the normalized spectra.

The performance of the best device (2.6\% doping rate) is reported in Fig. S21 as a function of the current density. The maximum EQE is $1.65 \%$ and the maximum current efficiency is $1 \mathrm{~cd} / \mathrm{A}$ at 2.5 $\mathrm{mA} / \mathrm{cm}^{2}$. The efficiencies drop at $20 \%$ from 0 to $50 \mathrm{~mA} / \mathrm{cm}^{2}$ in accordance with fluorescent OLEDs. The luminance is proportional to the current density with $400 \mathrm{~cd} / \mathrm{m}^{2}$ at current density of $50 \mathrm{~mA} / \mathrm{cm}^{2}$. Despite its modest device performances, these results are highly encouraging as this is, to our knowledge, the first insertion of a phosphepine-based emitter in an electroluminescent device. As 4, 5, and 6-membered P-rings have already been successfully inserted in OLEDs, these results confirm that $\pi$-conjugated P-heterocycles are highly appealing building blocks for lightning purpose..$^{[1 c, 5,13]}$

\section{Conclusions}

In conclusion, the straightforward synthesis of a new family of naphthyl-fused phosphepines 6-8 has been described. This synthetic approach uses a chlorophosphine-oxide $\mathbf{3}$ that display strong resistance to hydrolysis due to a combination of steric shielding and pnictogenic interaction. The exocyclic P-R group can be easily tuned using the particular reactivity of $\mathbf{3}$, opening the way toward functionalization of the compounds. ${ }^{[14]}$ These derivatives display a highly distorted polycylic backbone. Photophysical studies revealed that these compounds are emissive in solution and in the solid-state. The successful incorporation of 6 into a blue emitting OLED confirmed that organosphorus derivatives in general, and $\pi$-extended phosphepines in particular, are appealing building blocks to design emitting materials for plastic electronics.

\section{Experimental Section}

General procedure. All experiments were performed under argon atmosphere using standard Schlenk techniques. Commercially available reagents were used as received without further purification. Solvents were freshly purified using MBRAUN SPS-800 drying columns. Separations were performed by gravity column chromatography on basic alumina (Aldrich, Type 5016A, 150 mesh, $58 \AA$ ) or silica gel (Merck Geduran 60, 0.063-0.200 mm). ${ }^{1} \mathrm{H},{ }^{13} \mathrm{C}$, and ${ }^{31} \mathrm{P}$ NMR spectra were recorded on Bruker AV III 300 and $400 \mathrm{MHz}$ NMR spectrometers equipped with BBO or BBFO probeheads. Assignment of proton and carbon atoms is based on COSY, NOESY, edited-HSQC and HMBC experiments. ${ }^{1} \mathrm{H}$ and ${ }^{13} \mathrm{C}$ NMR chemical shifts were reported in parts per million (ppm) using residual solvent signal as reference. In the NMR description. High-resolution mass spectra were obtained on a Varian MAT 311 or ZabSpec TOF Micromass instrument at CRMPO (Scanmat, UMS 2001). UV-Visible spectra were recorded it on a VARIAN Cary 5000 spectrophotometer. The UV-Vis emission and excitation spectra measurements were recorded on a FL 920 Edimburgh Instrument equipped with a Hamamatsu R5509-73 photomultiplier for the NIR domain (300-1700 nm) and corrected for the response of the photomultiplier. Quantum yields in solution were calculated relative to quinine sulfate $\left(\mathrm{H}_{2} \mathrm{SO}_{4}, 0.1 \mathrm{M}\right)$, $\phi r e f=0.55$. The absolute quantum yields were measured with a C9920-03 Hamamatsu. The electrochemical studies were carried out under argon using an Eco ChemieAutolab PGSTAT 30 potentiostat for cyclic voltammetry with the three-electrode configuration: the working electrode was a platinum disk, the reference electrode was a saturated calomel electrode and the counter-electrode a platinum wire. All potential were internally referenced to the ferrocene/ ferrocenium couple. For the measurements, concentrations of $10^{-3} \mathrm{M}$ of the electroactive species were used in freshly distilled and degassed DMF and $0.2 \mathrm{M}$ tetrabutylammoniumhexafluorophosphate. Thermogravimetric Analysis were performed by using a Mettler-Toledo TGA-DSC-1 apparatus under dry nitrogen flow at a heating rate of $10^{\circ} \mathrm{C} / \mathrm{min}$

Experimental part. 2. 1,8-Dibromonaphtalene $(2 \mathrm{~g}, 7.1 \mathrm{mmol}, 3 \mathrm{eq})$ is dissolved in $80 \mathrm{~mL}$ of dry $\mathrm{Et}_{2} \mathrm{O}$. The solution is cooled down to $-80^{\circ} \mathrm{C}$ then BuLi $(2.8 \mathrm{~mL}, 7.1 \mathrm{mmol}, 3 \mathrm{eq})$ is added dropwise and the solution is stirred for $30 \mathrm{mn}$ at $-80^{\circ} \mathrm{C}$ then $30 \mathrm{mn}$ at $\mathrm{rt}$. The solution is again cooled down to $-80^{\circ} \mathrm{C}$ and $\mathrm{Ph}_{2} \mathrm{PCl}(0.423 \mathrm{mg}, 2.37 \mathrm{mmol}, 1 \mathrm{eq})$ is added dropwise. The mixture is then stirred at RT overnight. Then the solution is quenched with $16 \mathrm{~mL}$ of water. $25 \mathrm{~mL}$ of $\mathrm{DCM}$ are then added then $4 \mathrm{~mL}$ of $\mathrm{H}_{2} \mathrm{O}_{2}$. After $2 \mathrm{~h}$ of stirring, the solution is extracted with water and evaporated. The crude mixture was purified by silica gel chromatography using $\mathrm{DCM} / \mathrm{Et}_{2} \mathrm{O}$ $(85 / 15)$ to afford 2 as a white powder $(1.29 \mathrm{~g}, 99 \%){ }^{1} \mathrm{H}$ NMR $(400 \mathrm{MHz}$, $\left.\mathrm{CD}_{2} \mathrm{Cl}_{2}, 243 \mathrm{~K}\right): 8.11-8.02(\mathrm{~m}, 4 \mathrm{H}), 7.99-7.94(\mathrm{~m}, 3 \mathrm{H}), 7.84(\mathrm{dd}, J=8 \mathrm{~Hz}, J$ $=2 \mathrm{~Hz}, 1 \mathrm{H}), 7.67-7.52(\mathrm{~m}, 3 \mathrm{H}), 7.48-7.30(\mathrm{~m}, 6 \mathrm{H}) .{ }^{13} \mathrm{C} \mathrm{NMR}(100 \mathrm{MHz}$, $\mathrm{CD}_{2} \mathrm{Cl}_{2}, 273 \mathrm{~K}$ ): 138.0 (d, JC-p $\left.=150 \mathrm{~Hz}, \mathrm{C}_{\mathrm{q}}\right), 137.9$ (d, J C-P $\left.=14 \mathrm{~Hz}, \mathrm{CH}\right)$, 137.4 (d, Jc-p = 12 Hz, CH), 137.0 (d, Jc-p $=7$ Hz, Cq), 135.0 (d, Jc-p = 60 $\mathrm{Hz}, \mathrm{CH}$ ), 133.9 (d, Jc-p = 6 Hz, CH), 132.6 (d, J c-p = $260 \mathrm{~Hz}, \mathrm{C}_{\mathrm{q}}$ ), 132.4 (d, $\left.\mathrm{J}_{\mathrm{C}-\mathrm{P}}=2 \mathrm{~Hz}, \mathrm{C}_{\mathrm{q}}\right), 132.4(\mathrm{~s}, \mathrm{CH}), 131.3(\mathrm{~s}, \mathrm{CH}), 129.5$ (d, J c-p = $\left.53 \mathrm{~Hz}, \mathrm{CH}\right)$,

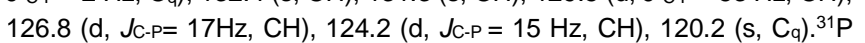
NMR (162 MHz, $\mathrm{CD}_{2} \mathrm{Cl}_{2}$ ) $\delta+42.9$. HRMS (ESI, $\left.\mathrm{CH}_{3} \mathrm{OH} / \mathrm{CH}_{2} \mathrm{Cl}_{2}: 9 / 1\right)$ : $[\mathrm{M}+\mathrm{Na}]^{+}\left(\mathrm{C}_{26} \mathrm{H}_{17} \mathrm{ONaBr}{ }_{2} \mathrm{P}\right) \mathrm{m} / \mathrm{z}$ Calcd for : 556.9276. m/z Found : 556.9274. Anal. Calcd for $\mathrm{C}_{26} \mathrm{H}_{17} \mathrm{Br}_{2} \mathrm{OP} .2 \mathrm{H}_{2} \mathrm{O}$ : C, 54.57; H, 3.70. Found: C, 53.77; H, 3.07 .

3. 1,8-Dibromonaphtalene ( $300 \mathrm{mg}, 1.06 \mathrm{mmol}, 4 \mathrm{eq}$ ) is dissolved in 20 $\mathrm{mL}$ of dry $\mathrm{Et}_{2} \mathrm{O}$. The solution is cooled down to $-80^{\circ} \mathrm{C}$ then BuLi $(0.42 \mathrm{~mL}$, $1.06 \mathrm{mmol}, 4 \mathrm{eq}$ ) is added dropwise and the solution is stirred for $30 \mathrm{mn}$ at $-80^{\circ} \mathrm{C}$ then $30 \mathrm{mn}$ at $\mathrm{rt}$. The solution is again cooled down to $-80^{\circ} \mathrm{C}$ and $\mathrm{PCl}_{3}$ (37 mg, $0.27 \mathrm{mmol}, 1 \mathrm{eq}$ ) is added dropwise. The mixture is then stirred at RT overnight. Then the solution is quenched with $4 \mathrm{~mL}$ of water. $6 \mathrm{~mL}$ of DCM are then added then $1 \mathrm{~mL}$ of $\mathrm{H}_{2} \mathrm{O}_{2}$. After $2 \mathrm{~h}$ of stirring, the 
solution is extracted with water and evaporated. The crude mixture was purified by silica gel chromatography using $\mathrm{DCM} / \mathrm{Et}_{2} \mathrm{O}(85 / 15)$ to afford 3 as a white powder (134 mg, $\left.99 \%) .{ }^{1} \mathrm{H} \mathrm{NMR} \mathrm{(400} \mathrm{MHz,} \mathrm{CD}_{2} \mathrm{Cl}_{2}, 223 \mathrm{~K}\right): 8.90$ (ddd, $J=20.1 \mathrm{~Hz}, J=7.5 \mathrm{~Hz}, J=2 \mathrm{~Hz}, 1 \mathrm{H}$ ), 8.22-8.13 (m, 2H), 8.09-8.02 $(\mathrm{m}, 2 \mathrm{H}), 7.94(\mathrm{t}, J=8.1 \mathrm{~Hz}, 2 \mathrm{H}), 7.76-7.69(\mathrm{~m}, 2 \mathrm{H}), 7.47-7.43(\mathrm{~m}, 1 \mathrm{H})$, 7.36-7.27 (m, 2H). ${ }^{13} \mathrm{C}$ NMR (100 MHz, $\left.\mathrm{CD}_{2} \mathrm{Cl}_{2}, 223 \mathrm{~K}\right) \delta 137.7$ (d, $J=8.8$ $\mathrm{Hz}), 136.6$ (d, $J=10.5 \mathrm{~Hz}), 136.1$ (d, $J=10.4 \mathrm{~Hz}), 135.6(\mathrm{~d}, J=20.5 \mathrm{~Hz})$, $135.3(\mathrm{~d}, J=3.5 \mathrm{~Hz}), 135.1(\mathrm{~d}, J=3.7 \mathrm{~Hz}), 131.9(\mathrm{~d}, J=5.6 \mathrm{~Hz}), 129.7$ $129.1(\mathrm{~m}), 127.1$ (d, $J=26.2 \mathrm{~Hz}), 124.6$ (d, $J=15.8 \mathrm{~Hz}), 124.0$ (d, $J=20.5$ $\mathrm{Hz}), 119.0(\mathrm{~d}, J=6.0 \mathrm{~Hz}) .{ }^{31} \mathrm{P}$ NMR $\left(162 \mathrm{MHz}, \mathrm{CD}_{2} \mathrm{Cl}_{2}\right) \delta+51.6$. HRMS $\left(\mathrm{ESI}, \mathrm{CH}_{3} \mathrm{OH} / \mathrm{CH}_{2} \mathrm{Cl}_{2}\right.$ : $\left.7 / 3\right)[\mathrm{M}+\mathrm{Na}]^{+}\left(\mathrm{C}_{20} \mathrm{H}_{12} \mathrm{OClBr}_{2} \mathrm{PNa}\right) \mathrm{m} / \mathrm{z}$ calcd $514.85732 \mathrm{~m} / \mathrm{z}$ Found : 514.8572. Anal. Calcd for $\mathrm{C}_{20} \mathrm{H}_{12} \mathrm{Br}_{2} \mathrm{ClOP}$ : found : C, 48.57; $\mathrm{H}, 2.45$. Found: $\mathrm{C}, 48.04 ; \mathrm{H}, 2.52$.

4. (General method $A$ ). $\mathrm{NaH}$ (129 mg, $3.235 \mathrm{mmol}, 4 \mathrm{eq}$ ) is dissolved in 40 $\mathrm{mL}$ of THF, then EtOH $(149 \mathrm{mg}, 3.235 \mathrm{mmol}, 4 \mathrm{eq})$ is added at $0^{\circ} \mathrm{C}$. Afte $1 \mathrm{~h} 30$ stirring, $3(400 \mathrm{mg}, 0.809 \mathrm{mmol}, 1 \mathrm{eq})$ is added at $0^{\circ} \mathrm{C}$, and the reaction is stirred at RT $2 \mathrm{~h}$. Then the solution is quenched with water, extracted with DCM and the solvents were evaporated. The crude mixture was purified by silica gel chromatography using DCM/Et $2 \mathrm{O}(9 / 1)$ to afford 4 as a white powder (320 mg, $78 \%) .{ }^{1} \mathrm{H}$ NMR $\left(400 \mathrm{MHz}, \mathrm{CD}_{2} \mathrm{Cl}_{2}, 293 \mathrm{~K}\right) \delta$ 8,82-7.49 (m, 8H), 7.54-7.34 (m, 4H), 4.19-3.98 (m, 2H), 1.39-1.28 (m, 3H). ${ }^{13} \mathrm{C}$ NMR (101 MHz, $\left.\mathrm{CD}_{2} \mathrm{Cl}_{2}\right) \delta 137.2\left(\mathrm{~s}, \mathrm{C}_{\mathrm{q}}\right), 135.4(\mathrm{~s}, \mathrm{CH}), 134.5(\mathrm{~s}$, $\mathrm{CH}), 133.6\left(\mathrm{~s}, \mathrm{C}_{\mathrm{q}}\right), 129.8(\mathrm{~s} \mathrm{CH}), 127.0\left(\mathrm{~s}, \mathrm{C}_{\mathrm{q}}\right), 124.9$ (d, Jc-p $=15.8 \mathrm{~Hz}$ $\mathrm{CH}), 120.4\left(\mathrm{~s}, \mathrm{C}_{\mathrm{q}}\right), 62.1\left(\mathrm{~s}, \mathrm{CH}_{2}\right), 16.1$ (d, Jc-p $\left.=1.6 \mathrm{~Hz}, \mathrm{CH}_{3}\right) .1 \mathrm{C}$ is not observable due to overlap. ${ }^{31} \mathrm{P}$ NMR $\left(162 \mathrm{MHz}, \mathrm{CD}_{2} \mathrm{Cl}_{2}\right) \delta+38.0$. HRMS (ESI, $\mathrm{CH}_{3} \mathrm{OH} / \mathrm{CH}_{2} \mathrm{Cl}_{2}$ : 9/1) $[\mathrm{M}+\mathrm{Na}]^{+}\left(\mathrm{C}_{22} \mathrm{H}_{17} \mathrm{OBr}_{2} \mathrm{NaP}\right) \mathrm{m} / \mathrm{z}$ Calcd $524.92251, \mathrm{~m} / \mathrm{z}$ Found : 524.9224 .

5. 5 was synthesized using General Method A with mesitol (396 mg, 2.91 $\mathrm{mmol}, 4 \mathrm{eq})$ and $3(360 \mathrm{mg}, 0.78 \mathrm{mmol}, 1 \mathrm{eq})$ to afford 5 as white powder (320 mg, $78 \%$ \%). ${ }^{1} \mathrm{H}$ NMR (400 MHz, $\left.\mathrm{CD}_{2} \mathrm{Cl}_{2}\right) \delta 8.69-8.63(\mathrm{~m}, 2 \mathrm{H}), 8.05(\mathrm{~d}$, $2 \mathrm{H}, \mathrm{J}=8.2 \mathrm{~Hz}), 7.9(\mathrm{~d}, 2 \mathrm{H}, \mathrm{J}=8.2 \mathrm{~Hz}), 7.76(\mathrm{~d}, 2 \mathrm{H}, \mathrm{J}=8.2 \mathrm{~Hz}), 7.50(\mathrm{t}$ $2 \mathrm{H}, \mathrm{J}=7.5 \mathrm{~Hz}), 7.30(\mathrm{t}, 2 \mathrm{H}, \mathrm{J}=7.8 \mathrm{~Hz}), 6.81(\mathrm{~s}, 2 \mathrm{H}), 2.24(\mathrm{~s}, 3 \mathrm{H}, \mathrm{Me})$ 2.06 (s, 6H, Me). $\left.{ }^{13} \mathrm{C} \mathrm{NMR} \mathrm{(101} \mathrm{MHz,} \mathrm{CD}_{2} \mathrm{Cl}_{2}\right) \delta 148.8$ (s, Cq), 137.2 (d, Jc $\mathrm{P}=9.1 \mathrm{~Hz}, \mathrm{CH}), 137.1\left(\mathrm{~d}, \mathrm{~J}_{\mathrm{c}-\mathrm{P}}=10.4 \mathrm{~Hz}, \mathrm{C}_{\mathrm{q}}\right), 134.9(\mathrm{~s}, \mathrm{CH}), 134.4\left(\mathrm{~d}, \mathrm{~J}_{\mathrm{c}}\right.$ $\mathrm{p}=3.4 \mathrm{~Hz}, \mathrm{CH}), 133.9\left(\mathrm{~d}, \mathrm{~J}_{\mathrm{c}-\mathrm{P}}=1.3 \mathrm{~Hz}, \mathrm{C}_{\mathrm{q}}\right), 133.6\left(\mathrm{~d}, \mathrm{~J}_{\mathrm{C}-\mathrm{P}}=8,1 \mathrm{~Hz}, \mathrm{C}_{\mathrm{q}}\right)$ 133.4 (d, Jc-p $=142.6 \mathrm{~Hz}, \mathrm{C}_{\mathrm{q}}$ ), 130.1 (d, Jc-p $\left.=3.4 \mathrm{~Hz}, \mathrm{C}_{\mathrm{q}}\right), 130.0(\mathrm{~s}, \mathrm{CH})$ $129.1\left(\mathrm{~d}, \mathrm{~J}_{\mathrm{c}-\mathrm{P}}=2.1 \mathrm{~Hz}, \mathrm{CH}\right), 126.9(\mathrm{~s}, \mathrm{CH}), 125.0\left(\mathrm{~d}, \mathrm{~J}_{\mathrm{c}-\mathrm{P}}=15.4 \mathrm{~Hz}, \mathrm{CH}\right)$ 120.1 (d, Jc-p $\left.=5.1 \mathrm{~Hz}, \mathrm{C}_{\mathrm{q}}\right), 20.7$ (s, Me), 19.1 (s, Me). ${ }^{31} \mathrm{P}$ NMR $(162 \mathrm{MHz}$ $\left.\mathrm{CD}_{2} \mathrm{Cl}_{2}\right) \delta+29.7$. HRMS (ESI, $\left.\mathrm{CH}_{3} \mathrm{OH}\right)[\mathrm{M}+\mathrm{Na}]^{+}\left(\mathrm{C}_{29} \mathrm{H}_{23} \mathrm{Br}_{2} \mathrm{NaO}_{2} \mathrm{P}\right)(\mathrm{ESI}$ $\mathrm{CH}_{3} \mathrm{OH} / \mathrm{CH}_{2} \mathrm{Cl}_{2}: 90 / 10$ ) m/z Calcd : 614,96946 m/z Found : 614.9691 . 6. (general method B) 2 ( $200 \mathrm{mg}, 0.372 \mathrm{mmol}, 1 \mathrm{eq}$ ) and 2,2 bipyridine (116 mg, $0.746 \mathrm{mmol}, 2 \mathrm{eq}$ ) are dissolved in $400 \mathrm{~mL}$ of dry THF and degassed for $20 \mathrm{mn}$. COD (0.09, $0.746 \mathrm{mmol}, 2 \mathrm{eq})$ and Ni(COD) 2 ( 206 $\mathrm{mg}, 0.746 \mathrm{mmol}, 2 \mathrm{eq}$ ) are added and the solution is stirred overnight at $25^{\circ} \mathrm{C}$ then $20 \mathrm{~mL}$ of $\mathrm{MeOH}$ are added. The mixture is filtered on $\mathrm{MgSO}_{4}$ washed with $\mathrm{Et}_{2} \mathrm{O}$ and the THF is evaporated. The crude mixture was purified by silica gel chromatography using DCM/AcOEt (1/1) to afford 6 as a white powder (108 mg, $78 \%)$. ${ }^{1} \mathrm{H}$ NMR $\left(400 \mathrm{MHz}, \mathrm{CD}_{2} \mathrm{Cl}_{2}\right) \delta 8,77$ (ddd, $2 \mathrm{H}, \mathrm{J}=14.4 \mathrm{~Hz}, \mathrm{~J}=6.9 \mathrm{~Hz}, \mathrm{~J}=1.4 \mathrm{~Hz}, \mathrm{H} 8$ ), 8.15 (d, $2 \mathrm{H}, \mathrm{J}=8.1 \mathrm{~Hz}$ $\left.\mathrm{H}_{6}\right), 7.95\left(\mathrm{~d}, 2 \mathrm{H}, \mathrm{J}=7.7 \mathrm{~Hz}, \mathrm{H}_{2}\right.$ or 4$), 7.75\left(\mathrm{t}, 2 \mathrm{H}, \mathrm{J}=7.4 \mathrm{~Hz}, \mathrm{H}_{7}\right), 7.55-7.49$ ( $\mathrm{m}, 4 \mathrm{H}, \mathrm{H}_{3}$ and $\mathrm{H}_{20 r}$ ) , 7.15-7.11 (m, $\left.1 \mathrm{H}, \mathrm{H}_{\text {para }}\right), 6.95-6.99$ (m, $2 \mathrm{H}, \mathrm{H}_{\text {meta }}$ ), 6.82-6.77 (m, 2H, Hortho). ${ }^{13} \mathrm{C}$ NMR (101 MHz, $\mathrm{CD}_{2} \mathrm{Cl}_{2}$ ) $\delta 140.1$ (d, Jc-p $=$ $\left.2,0 \mathrm{~Hz}, \mathrm{C}_{1}\right), 137.6$ (d, J $\left.\mathrm{J}_{\mathrm{c}-\mathrm{P}}=118 \mathrm{~Hz}, \mathrm{C}_{\mathrm{ipso}}\right), 136.1$ (s, CH), 134.7 (d, Jc-p = $\left.4,5 \mathrm{~Hz}, \mathrm{C}_{8}\right), 133.9$ (d, JC-p $\left.=2,9 \mathrm{~Hz}, \mathrm{C}_{6}\right), 133.8$ (d, Jc-p $\left.=10,1 \mathrm{~Hz}, \mathrm{C}_{5}\right)$, 132.1 (d, J $\mathrm{J}_{-} \mathrm{P}=11,4 \mathrm{~Hz}, \mathrm{C}_{10}$ ), 131.0 (d, J $\left.\mathrm{c}-\mathrm{P}=2,3 \mathrm{~Hz}, \mathrm{C}_{\mathrm{para}}\right), 130.1$ (s, CH) 130.1 (d, Jc-p $=10,4 \mathrm{~Hz}, \mathrm{C}_{\text {ortho }}$ ), 128.5 (d, Jc-p $=12,1 \mathrm{~Hz} \mathrm{C}_{9}$ ), 128.1 (d, Jc-P $\left.=12,1 \mathrm{~Hz}, \mathrm{C}_{\text {meta }}\right), 126.7(\mathrm{~s}, \mathrm{CH}), 125.6\left(\mathrm{~d}, \mathrm{~J}_{\mathrm{C}-\mathrm{P}}=12.1 \mathrm{~Hz}, \mathrm{C}_{7}\right) .{ }^{31} \mathrm{P}$ NMR (162 $\left.\mathrm{MHz}, \mathrm{CD}_{2} \mathrm{Cl}_{2}\right) \delta+22.7$. HRMS (ESI, $\mathrm{CH}_{3} \mathrm{CN} / \mathrm{CH}_{2} \mathrm{Cl}_{2}: 80 / 20$ ) $[\mathrm{M}+\mathrm{H}]^{+}\left(\mathrm{C}_{26} \mathrm{H}_{18} \mathrm{OP}\right) \mathrm{m} / \mathrm{z}$ Calcd : $377.10898 \mathrm{~m} / \mathrm{z}$ Found : 377.1088. Anal. Calcd for $\mathrm{C}_{26} \mathrm{H}_{17} \mathrm{OP}: \mathrm{C}, 82.97 ; \mathrm{H}, 4.55$. Found: $\mathrm{C}, 81.39 ; \mathrm{H}, 4.62$

7. General method $B$ was used using $4(100 \mathrm{mg}, 0.198 \mathrm{mmol}, 1 \mathrm{eq})$ The crude mixture was purified by silica gel chromatography using DCM/AcOEt $(1 / 1)$ to afford 7 as a white powder $(36 \mathrm{mg}, 53 \%) .{ }^{1} \mathrm{H}$ NMR $(400 \mathrm{MHz}$, $\mathrm{CD}_{2} \mathrm{Cl}_{2}$ ) $\delta 8,58$ (ddd, $\left.2 \mathrm{H}, \mathrm{J}=14.9 \mathrm{~Hz}, \mathrm{~J}=6.9 \mathrm{~Hz}, \mathrm{~J}=1.5 \mathrm{~Hz}, \mathrm{H}_{8}\right), 8.15(\mathrm{~d}$ $\left.2 \mathrm{H}, \mathrm{J}=8.1 \mathrm{~Hz}, \mathrm{H}_{6}\right), 7.97\left(\mathrm{~d}, 2 \mathrm{H}, \mathrm{J}=7.7 \mathrm{~Hz}, \mathrm{H}_{2}\right.$ or 4$), 7.69-7.61\left(\mathrm{~m}, 6 \mathrm{H}, \mathrm{H}_{7}\right.$ $\mathrm{H}_{3}$ and $\mathrm{H}_{2}$ or 4 ), 3.03 (q, $\left.2 \mathrm{H},, \mathrm{J}=7.2 \mathrm{~Hz}, \mathrm{H}_{11}\right), 0.55$ (t, $3 \mathrm{H}, \mathrm{J}=7.5 \mathrm{~Hz}, \mathrm{H}_{12}$ ) ${ }^{13} \mathrm{C}$ NMR (101 MHz, CD $\left.\mathrm{Cl}_{2}\right) \delta 140.5$ (d, Jc-p $\left.=1.9 \mathrm{~Hz}, \mathrm{C}_{\mathrm{q}}\right), 136.2$ (s, $\left.\mathrm{C}_{7}\right), 134.3$ (d, Jc-p = 3.0 Hz, C6), 134.1 (d, Jc-p $=11.5 \mathrm{~Hz}, \mathrm{C}_{\mathrm{q}}$ ), 134.1 (d, Jc $\left.\mathrm{P}=5.8 \mathrm{~Hz}, \mathrm{C}_{8}\right), 132.2\left(\mathrm{~d}, \mathrm{~J}_{\mathrm{c}-\mathrm{P}}=11.6 \mathrm{~Hz}, \mathrm{C}_{\mathrm{q}}\right), 130.0\left(\mathrm{~d}, \mathrm{~J}_{\mathrm{c}-\mathrm{P}}=1.8 \mathrm{~Hz}, \mathrm{C}_{2}\right.$ or 4), 127.6 (d, Jc-p $\left.=129.5 \mathrm{~Hz}, \mathrm{C}_{9}\right), 126.8$ ( $\mathrm{s}, \mathrm{C}_{3}$ or 7 ), 125.1 (d, Jc-p $=13.5 \mathrm{~Hz}$ $\mathrm{C}_{3 \circ \mathrm{or}}$ ), 60.2 (s, $\mathrm{CH}_{2}$ ), 15.8 (d, Jc-P $\left.=1.6 \mathrm{~Hz}, \mathrm{CH}_{3}\right) .{ }^{31} \mathrm{P} \mathrm{NMR}(162 \mathrm{MHz}$,
$\left.\mathrm{CD}_{2} \mathrm{Cl}_{2}\right): \delta+27.2 . \mathrm{HRMS}\left(\mathrm{ESI}, \mathrm{CH}_{3} \mathrm{OH} / \mathrm{CH}_{2} \mathrm{Cl}_{2}: 9 / 1\right)[\mathrm{M}+\mathrm{Na}]^{+}\left(\mathrm{C}_{22} \mathrm{H}_{17} \mathrm{O}_{2} \mathrm{Na}\right.$ P) $\mathrm{m} / \mathrm{z}$ Calcd : 367.0854, $\mathrm{m} / \mathrm{z}$ Found : 367.0857 .

8. General Method B was used with $5(65 \mathrm{mg}, 0.109 \mathrm{mmol}, 1 \mathrm{eq})$ to afford 8 as white powder (38 mg, $47 \%$ ). ${ }^{1} \mathrm{H}$ NMR $\left(400 \mathrm{MHz}, \mathrm{CD}_{2} \mathrm{Cl}_{2}\right) \delta 8,58$ (ddd $\left.2 \mathrm{H}, \mathrm{J}=15.3 \mathrm{~Hz}, \mathrm{~J}=6.9 \mathrm{~Hz}, \mathrm{~J}=1.5 \mathrm{~Hz}, \mathrm{H}_{8}\right), 8.19\left(\mathrm{~d}, 2 \mathrm{H}, \mathrm{J}=8.2 \mathrm{~Hz}, \mathrm{H}_{6}\right)$, $8.00\left(\mathrm{~d}, 2 \mathrm{H}, \mathrm{J}=8.0 \mathrm{~Hz}, \mathrm{H}_{2}\right.$ or 4$), 7.75\left(\mathrm{~d}, 2 \mathrm{H}, \mathrm{J}=7.5 \mathrm{~Hz} \mathrm{H}_{2}\right.$ or 4$), 7.69-7.64$ $\left(\mathrm{m}, 4 \mathrm{H}, \mathrm{H}_{7}\right.$ and $\left.\mathrm{H}_{3}\right), 6.58\left(\mathrm{~s}, 2 \mathrm{H}, \mathrm{H}_{14}\right), 2.10\left(\mathrm{~s}, 3 \mathrm{H}, \mathrm{H}_{16}\right), 1.33\left(\mathrm{~s}, 6 \mathrm{H}, \mathrm{H}_{13}\right) .{ }^{13} \mathrm{C}$ $\operatorname{NMR}\left(101 \mathrm{MHz}, \mathrm{CD}_{2} \mathrm{Cl}_{2}\right) \delta 146.5$ (s, Jc-p $\left.=10.0 \mathrm{~Hz}, \mathrm{C}_{11}\right), 140.4$ (d, Jc-p $=$ $\left.1.9 \mathrm{~Hz}, \mathrm{C}_{\mathrm{q}}\right), 136.4$ (s, $\mathrm{C}_{2}$ or 4$), 134.5$ (d, Jc-p $\left.=3.0 \mathrm{~Hz}, \mathrm{C}_{6}\right), 134.4$ (d, Jc-p = $\left.11.6 \mathrm{~Hz}, \mathrm{C}_{q}\right), 134.2\left(\mathrm{~d}, \mathrm{~J}_{\mathrm{c}-\mathrm{P}}=2.1 \mathrm{~Hz}, \mathrm{C}_{\mathrm{q}}\right), 133.4\left(\mathrm{~d}, \mathrm{~J}_{\mathrm{c}-\mathrm{P}}=6.2 \mathrm{~Hz}, \mathrm{C}_{8}\right)$, 132.3 (d, JC-P $=11.7 \mathrm{~Hz}, \mathrm{C}_{\mathrm{q}}$ ), 130.6 (d, Jc-p $\left.=3.0 \mathrm{~Hz}, \mathrm{C}_{\mathrm{q}}\right), 130.1\left(\mathrm{~d}, \mathrm{~J}_{\mathrm{C}-\mathrm{P}}=\right.$ $1.9 \mathrm{~Hz}, \mathrm{C}_{2}$ or 4), 129.4 (d, Jc-p $\left.=2.0 \mathrm{~Hz}, \mathrm{C}_{14}\right), 128.2$ (s, $\mathrm{C}_{\mathrm{q}}$ ), 127.0 (s, $\mathrm{C}_{3}$ o 7), $125.2\left(\mathrm{~d}, \mathrm{~J}_{\mathrm{c}-\mathrm{P}}=3.7 \mathrm{~Hz}, \mathrm{C}_{3}\right.$ or 7$), 20.6\left(\mathrm{~s}, \mathrm{C}_{16}\right), 17.2\left(\mathrm{~s}, \mathrm{C}_{13}\right){ }^{31} \mathrm{P} \mathrm{NMR}$ (162 $\left.\mathrm{MHz}, \mathrm{CD}_{2} \mathrm{Cl}_{2}\right) \delta+$ 28.1. HRMS (ESI, $\mathrm{CH}_{3} \mathrm{OH} / \mathrm{CH}_{2} \mathrm{Cl}_{2}: 9 / 1$ ) $[\mathrm{M}+\mathrm{Na}]^{+}\left(\mathrm{C}_{29} \mathrm{H}_{23} \mathrm{O}_{2} \mathrm{NaP}\right) \mathrm{m} / \mathrm{z}$ Calcd : 457.13279, Found: 457.131.

\section{X-ray crystallography}

Single crystals suitable for X-Ray crystal analysis were obtained by slow diffusion of vapours of pentane into a dichloromethane solution of the derivatives at rt. Single crystal data collection were performed at $150 \mathrm{~K}$ with an D8 Venture Bruker-AXS diffractometer with Mo-Ka radiation $(\lambda=$ $0.71073 \AA$ ). The structure was solved by dual-space algorithm using the SHELXT program, and then refined with full-matrix least-squares methods based on $F^{2}(S H E L X L)$. All non-hydrogen atoms were refined with anisotropic atomic displacement parameters. $\mathrm{H}$ atoms were finally included in their calculated positions and treated as riding on their parent atom with constrained thermal parameters.

\section{Computational details.}

The computations were performed with the Gaussian 09 program package. ${ }^{[15]}$ All structures were optimised using the B3LYP, B3LYPD3 and $\omega B 97 X D$ functionals combined with the $6-31+G^{*}$ basis set. At each of the optimised structures vibrational analysis was carried out to check that the stationary point located is a minimum of the potential energy hypersurface (no imaginary frequencies were obtained) or a transition state (one imaginary frequency). The Wiberg Bond Indices were calculated with the NBO program version 3.1. ${ }^{[16]}$ The AIM analysis was obtained with the Multiwfn code. ${ }^{[1]}$ The molecular orbitals were plotted with Avogadro program. ${ }^{[18]}$

\section{OLEDs fabrication and characterisation}

The OLED devices were fabricated onto indium tin oxide (ITO) glass substrates purchased from Xin Yang Technology (90 nm thick, sheet resistance of $15 \Omega / \Upsilon$ ). Prior to organic layer deposition, the ITO substrates were cleaned by sonication in a detergent solution, rinsed twice in deionized water and then in isopropanol solution and finally treated with UVozone during 15 minutes. The OLEDs stack used is: Glass / ITO / CuPc $(10 \mathrm{~nm}) / \mathrm{\alpha}-\mathrm{NPB}(40 \mathrm{~nm}) / \mathrm{EML}(20 \mathrm{~nm}) / \mathrm{TmPyPB}(40 \mathrm{~nm}) / \mathrm{LiF}(1.2 \mathrm{~nm})$ / $\mathrm{Al}(100 \mathrm{~nm})$. Copper II phthalocyanine (CuPc) is used as hole injection layer (HIL), N, N'-Bis-(1-naphthalenyl)- N,N'-bis-phenyl-(1,1'-biphenyl)4,4'-diamine (aNPB) as hole transport layer (HTL), 1,3,5-Tri(m-pyridin-3ylphenyl) benzene, 1,3,5-Tris(3-pyridyl-3-phenyl) benzene (TmPyPB) as electron transport layer (ETL), lithium fluoride as electron injection layer (EIL) and $100 \mathrm{~nm}$ of aluminum as the cathode, respectively. The emitting layer (EML) is a host-guest system of $20 \mathrm{~nm}$ thick with 1,3-Bis $(N$ carbazolyl)benzene $(\mathrm{mCP})$ as the host and molecule $\mathbf{6}$ as the guest (doping ratio $0-70 \%$ weight). Organic layers were sequentially deposited onto the ITO substrate at a rate of $0.2 \mathrm{~nm} / \mathrm{s}$ under high vacuum $\left(10^{-7} \mathrm{mbar}\right)$. The doping rate was controlled by simultaneous co-evaporation of the host and the dopant. An in-situ quartz crystal was used to monitor the thickness of the layer depositions with an accuracy of $5 \%$. The active area of the devices defined by the Al cathode was $0.3 \mathrm{~cm}^{2}$. The organic layers and the $\mathrm{LiF} / \mathrm{Al}$ cathode were deposited in a one-step process without breaking the vacuum.

After deposition, all the measurements were performed at $\mathrm{rt}$ and under ambient atmosphere with no further encapsulation of devices. The current-voltage-luminance $(\mathrm{I}-\mathrm{V}-\mathrm{L})$ characteristics of the devices were 
measured with a regulated power supply (ACT100 Fontaine) combined with a multimeter (Keithley) and $1 \mathrm{~cm}^{2}$ area silicon calibrated photodiode (Hamamatsu). Electroluminescence (EL) spectra and chromaticity coordinates of the devices were recorded with a PR650 SpectraScan spectrophotometer, with a spectral resolution of $4 \mathrm{~nm}$.

\section{Acknowledgements}

This work is supported by the Ministère de la Recherche et de l'Enseignement Supérieur, the CNRS, the Région Bretagne, the

[1] (a) T. Baumgartner, R. Réau, Chem Rev, 2006, 106, 4681-4727. (b) M Hissler, P. W. Dyer, R. Réau, Coord. Chem. Rev. 2003, 244, 1-44 (c) D. Joly, P. A. Bouit, M. Hissler, J. Mater. Chem. C 2016, 4, 36863698. (d) M. Stolar, T. Baumgartner, Chem. As. J.I 2014, 9, 1212 1225

[2] J. I. Bates, J. Dugal-Tessier, D. P. Gates, Dalton Trans. 2010, 39, 3151 3159.

[3](a) P.-A. Bouit, A. Escande, R. Szücs, D. Szieberth, C. Lescop, L. Nyulászi M. Hissler, R. Réau, J. Am. Chem. Soc. 2012, 134, 6524-6527 ; (b) H. Omori, S. Hiroto, Y. Takeda, H. Fliegl, S. Minakata, H. Shinokubo, J. Am. Chem. Soc. 2019, 141124800-4805.

[4] (a) F. Mathey, Chem. Rev. 1988, 88, 429-453; (b) M. P. Duffy, W. Delaunay, P. A. Bouit, M. Hissler, Chem. Soc. Rev. 2016, 45, 5296-5310; (c) Y. Ren, T Baumgartner, Dalton Trans. 2012, 41, 7792-7800 ; (d) Y. Matano, H. Imahori, Org. Biomol. Chem. 2009, 7, 1258-1271.

[5] H. Chen, S. Pascal, Z. Wang, P.-A. Bouit, Z. Wang, Y. Zhang, D. Tondelier, B. Geffroy, R. Réau, F. Mathey, Z. Duan, M. Hissler, Chem. Eur. J. 2014, 20 9784-9793

[6] (a) C. Müller, L. E. E. Broeckx, I. de Krom, J. J. M. Weemers, Eur. J. Inorg Chem. 2013, 2013, 187-202; (b) E. Regulska, C. Romero-Nieto, Dalton Trans. 2018, 47, 10344-10359.

[7] (a) X. He, J. Borau-Garcia, A. Y. Y. Woo, S. Trudel, T. Baumgartner, J. Am Chem. Soc. 2013, 135, 1137-1147 ; (b) Y. Ren, M. Sezen, F. Guo, F. Jäkle, Y. L. Loo, Chem. Sci. 2016, 7, 4211-4219; (c) W. Winter,Chem. Ber. 1976, 109, 1405-2419; (d) D. Wu, C. Hu, L. Q, Z. Duan, F. Mathey Eur. J. Org. Chem. 2019 10.1002/ejoc.201901165.

[8] a) V. Lyaskovskyy, R. J. A. van Dijk-Moes, S. Burck, W. I. Dzik, M. Lutz, A W. Ehlers, J. C. Slootweg, B. de Bruin, K. Lammertsma, Organometallics 2013 32, 363-373; (b) T. Delouche, A. Mocanu, T. Roisnel, R. Szűcs, E. Jacques, Z. Benkő, L. Nyulászi, P.-A. Bouit, M. Hissler, Org. Lett. 2019, 21, 802-806. [9] K. Schickedanz, J. Radtke, M. Bolte, H.-W. Lerner, M. Wagner, J. Am. Chem Soc. 2017, 139, 2842-2851.

[10] Note that similar values have been reported for pnictogen interactions previously: S. Zahn, R. Frank, E. Hey-Hawkins and B. Kirchner, Chem. Eur. J. 2011, 17, 6034-6038.
French National Research Agency (ANR Heterographene ANR16-CE05-0003-01, ANR Fluohyb ANR-17-CE09-0020), OTKA NN 113772 and BME-Nanonotechnology FIKP grant of EMMI (BME FIKP-NAT), PICS SmartPAH (08062). Y. Molard and G. Taupier (Scanmat-UMS 2001) are thanked for luminescence quantum yields measurements.

Keywords: $\pi$-conjugated systems $\cdot$ P-heterocycles $•$ Optica properties $\cdot$ DFT calculations $\bullet$ OLED

[11] Pnictogen bonding similarly to other so-called $\sigma$-hole interactions (hydrogen bond, halogen bond, etc.) is chiefly electrostatic interaction with minor covalent character (charge transfer) arising between a pnictogen center and a Lewis base: (a) S. Scheiner, Acc. Chem. Res. 2013, 46, 280- 288, (b) J. Moilanen, C. Ganesamoorthy, M. S. Balakrishna, H. M. Tuononen, Inorg. Chem. 2009, 48 6740-6747. (c) S. Scheiner, Noncovalent forces, Springer, Cham, 2015.

[12] (a) Y. Hong, J. W. Y. Lam, B. Z. Tang, Chem. Soc. Rev.2011, 40, 5361 5388; (b) F. Riobé, R. Szücs, P.-A. Bouit, D. Tondelier, B. Geffroy, F. Aparicio J. Buendía, L. Sánchez, R. Réau, L. Nyulászi, M. Hissler, Chem. Eur. J. 2015 21, 6547-6556

[13] (a) C. Fave, T. Y. Cho, M. Hissler, C. W. Chen, T. Y. Luh, C. C. Wu and R. Réau, J. Am. Chem. Soc., 2003, 125, 9254; (b) P. Hindenberg, J. Zimmermann G. Hernandez-Sosa, C. Romero-Nieto, Dalton Trans.2019, 8, 7503-7508.

[14] Z. Wang, B. S. Gelfand, T. Baumgartner, Angew. Chem. Int. Ed. 2016, 55, 3481-3485.

[15] Gaussian 09, Revision E.01, M. J. Frisch, G. W. Trucks, H. B. Schlegel, G. E. Scuseria, M. A. Robb, J. R. Cheeseman, G. Scalmani, V. Barone, B. Mennucci, G. A. Petersson, H. Nakatsuji, M. Caricato, X. Li, H. P. Hratchian, A. F. Izmaylov, J. Bloino, G. Zheng, J. L. Sonnenberg, M. Hada, M. Ehara, K. Toyota, R. Fukuda, J. Hasegawa, M. Ishida, T. Nakajima, Y. Honda, O. Kitao, H. Nakai, T. Vreven, J. A. Montgomery, Jr., J. E. Peralta, F. Ogliaro, M. Bearpark, J. J. Heyd, E Brothers, K N Kudin, V N Staroverov, T Keith, R Kobayashi, J. Normand, K. Raghavachari, A. Rendell, J. C. Burant, S. S. lyengar, J. Tomasi, M. Cossi, N. Rega, J. M. Millam, M. Klene, J. E. Knox, J. B. Cross, V. Bakken, C. Adamo, J. Jaramillo, R. Gomperts, R. E. Stratmann, O. Yazyev, A. J. Austin, R. Cammi, C. Pomelli, J. W. Ochterski, R. L. Martin, K. Morokuma, V. G. Zakrzewski, G. A. Voth, P. Salvador, J. J. Dannenberg, S. Dapprich, A. D. Daniels, O. Farkas, J. B. Foresman, J. V. Ortiz, J. Cioslowski, and D. J. Fox, Gaussian, Inc., Wallingford CT, 2013

[16] NBO Version 3.1 by E. D. Glendening, A. E. Reed, J. E. Carpenter, F. Weinhold

[17] Lu, T.; Chen, F. J. Comput. Chem. 2012, 33, 580-592

[18] https://avogadro.cc/ 